\title{
Ownership on Islamic Economic Perspective and Director Ownership on Sharia Companies with Moderation Roles of Independent Commissioners
}

\author{
Muhammad Noval', Rani Raharjanti ${ }^{2}$, \\ Musab A. M. Ali ${ }^{3}$ \\ UIN Antasari Banjarmasin ${ }^{\mathrm{I}}$, Politeknik Negeri Semarang', \\ Management and Science University ${ }^{3}$ \\ noval@uin-antasari.ac.id,rani.raharjanti@polines.ac.id, \\ drmusab@msu.edu.my
}

\begin{abstract}
This research aims to examine the ownership on Islamic economic and the ownership stock effect on firm performance and the moderating influence of independent commissioner on the connection between ownership stock and firm performance. Indicator of ownership stock studied was the ownership stock of the president director in the company. The firm performance studied by the calculation of Price per Earning Ratio. Then, the intended independent commissioners are the percentage of independent commissioners who are on the company's board of commissioners.

This research uses qualitaitive method based on Islamic economic literature and quantitative methods basedon secondary data. Secondary data in this research are the financial report from firms that take the floor on Indonesia Stock Exchange (IDX). This investigation uses a population that is listed firms on Indonesian Sharia Stock Index (ISSI). Subsequently, the sample is filtered using purposive sampling techniques with the criteria of listed firms on Indonesia Stock Exchange and has the data needed in this investigation. As a result, the samples obtained were 296 companies. This research uses regression analysis with individual parameter significant test ( $\mathrm{t}$-test).
\end{abstract}


Hypothesis testing results indicate that Sharia company ownershipis in accordance with Islamic economic perspective studies, and ownership stock with the indicator of ownership of the president director has an impact on firm performance with Price per Earning Ratio's indicator, and independent commissioners based on the proportion of independent commissioners on the board of commissioners moderate the correlation between ownership stock and firm performance.

\section{Keywords: Ownership Stock, Firm Performance, and Independent} Commissioners.

\section{A. INTRODUCTION}

One of the crucial elements to improve the performance of an organization or company is one of them with the right, good, and right corporate governance. If good governance implemented in the company, it will also be in line with the firm's performance improvement. One of the characteristics of good governance is the effectiveness of corporate governance itself, thus it will encourage an increase firm's financial performance. Research that has conducted relating to corporate governance based on the composition and function of the board of commissioners as a driver and supervisor of the company regarding good governance is research that can provide additional insight and knowledge to improve and enhance corporate governance in economic aspects for developing countries just like in Indonesia.

Agency theory, conveyed by Jensen \& Meckling, 1976, is the basis of corporate governance development. In this theory, it is defining and interpreting the relationship that occurs between an agent (manager) and principal (owner). The agent is a party that has a duty as a manager of a company that is given the trust and mandate to manage the company as well as possible by the owner of the company called the principal. The agent or manager of the company has an obligation to the owner of the company or the principal to take responsibility for managing the company.

The manager, as an agent, will be seen as a party who will act in his interests by ignoring the interests of the owner of the company. The inequality of interests between company owners and company managers will trigger agency problems. 
Jensen \& Meckling, 1976, the imbalance of information can lead to two problems, including:

a. Moral Hazard

Moral Hazard is a problem that will arise when the agent (manager) does not carry out a collective agreement that has stated in the employment contract with the principal (shareholder).

b. Adverse selection

Adverse selection is a condition when the principal cannot understand the policies that have been made by the manager (agent) based on information that has been obtained or can be due to carelessness in carrying out the obligations that have been given.

Florentina Widita Sari (Sari, 2012) explain good governance is:

a. The structure of the relationship between the functions of the General Meeting of Shareholders (GMOS), Commissioners, Directors, and stakeholders;

b. The Check and Balance mechanism as an authority control over a company's internal control;

c. The rights of shareholders (principals) to company information clearly and accurately following the agreed period; and

d. Disclosure of all information about company ownership, firm performance, and stakeholders that is accurate, open, and timely.

The structure of capital funding contribution is believed to have an impact on the company's management, which in turn can also impact on the firm's performance in achieving the firm's objectives to the fullest. It is because there is control over the shareholders (principals) (Wahyudi \& Pawestri, 2006). Director who owns shares (in this study is called the Ownership Stock) refers to the potential of management to own leverage or position to pursue their own goals. Director who has uncontrolled power by an independent commissioner, is more likely to take action in his interests which reduce shareholder wealth (Dunn, 2004); (Frankforter, Berman, \& Jones, 2000).

The power of ownership reflects the level of economic importance or voting rights that an executive has in an organization. Executives are most responsible to the owner of the company. Therefore, the highest manager with significant ownership will have more power than management who does not have stock ownership. The strength of share ownership gives more power and rights in 
the management meeting room where the company decides matters through voting (Larcker \& Tayan, 20I2).

Ownership of personal wealth is considered as a motivation to stimulate humanity's best efforts to expand the wealth of society. The theory of ownership in Islam views personal ownership as unique. Ownership, in essence, is God's ownership, while only a part of it, under certain conditions, belongs to man so that he can fulfill God's purpose. The intended purpose of God is to represent the goals of society by acting as guardians for those in need.

Personal ownership of the Islamic view is not absolute. Because in Islam the provisions of the law are found in certain restrictions and controls that a Muslim cannot override in the management and use of his property. So in fact in Islam individual ownership is recognized but there are Shariah rules and they must represent the wider community. So it is expected that from the possession of wealth owned by each individual can provide welfare for the company and also the stakeholders. As Allah says:

"Believe in Allah and His Messenger and give up some of your wealth which Allah has given you." (QS. Al-Hadiid: 7)

Independent commissioners are expected to provide guarantees for the creation of financial statements as a whole can interpret and truthfully about the company's operations, to prevent the possibilities of fraud by the management (Tutut Dwi Andayani, 2010). Mark S. Beasley, 1996, has examined research on the proportion of the board of commissioners with financial statement deviations. As a result, companies with smaller independent commissioners have a higher indication of committing fraud. Research from Nasution \& Setiawan, 2007shows that earnings management is significantly negatively affected by the proportion of independent directors. Commissioners who are not bound are expected to be able to reduce cheating practices because they can be more effective and independent in overseeing management performance (Parulian, 2004).

Firm performance analysis can be done with technical analysis methods and also fundamental analysis. Technical analysis will use stock price charts every day, while fundamental analysis by analyzing performance based on the financial statements. In this analysis, there are quite a lot of analysis tools. From many analytical tools, a popular analytical tool is the analysis of the ratio of price to net profit or called Price per Earning Ratio (PER), investors and potential investors can easily conduct stock analysis using this ratio. PER is a financial statement analysis tool that included in the market ratio category, and PER is also a 
measurement tool in determining the value of a company based on mechanisms in the capital market. Investors or potential investors can predict the possibility of profits generated by the company in the future by using PER analysis. Investors can examine the company's financial performance to provide confidence in determining the investment to be made. A large PER is an indicator of the possibility of company growth, which is also high; on the contrary, a small PER shows low company growth (Lusiana \& Chabachib, 2010).

Many variables can influence PER, and evidence from research Mpataa \& Sartono, I997; the test results found that PER influenced by several factors, including leverage ratio, fixed assets, total sales, profit growth, company scale, return on equity (ROE) and dividend payout ratio (DPR).

Empirical evidence from research on outside independent commissioners and company performance is very diverse. Several studies, such as Schellenger, Wood, \& Tashakori, I989, and Catherine M. Daily \& Dan R. Dalton, I992, prove that the presence of a greater number of independent directors on the board of commissioners can make the company's economic performance improve.

Whereas in another researches (Baysinger \& Butler, I985), (Chaganti, Mahajan, \& Sharma, I985), (Rechner \& Dalton, I986), (Hermalin \& Weisbach, I99I)and(Cho \& Kim, 2007) could not find a relationship between composition the board in the form of representation from outside independent commissioners and firm performance.

There are various results from researches on corporate governance and firm performance. The variety of results that can be caused by the research variables used by each researcher also differ (Deni Darmawati, Khomsiyah Khomsiyah, \& Rika Gelar Rahayu, 2005). Thus, the use of different variables and research objects for further research is still very relevant. This research moved from the existence of differences in the results of research that had been done and retested the moderating variables of independent commissioners on the relationship of independent variables of Director ownership (ownership stock) and firm performance using Islamic companies as the object of this research.

This research is a development of Khan \& Awan, research, 2012, about the effect of board composition on firm performance, by using independent variables in the form of an independent board and dependent board composition in all companies listed on the Pakistan Stock Exchange (PSX). This research is also a further research development from previous studies using objects of manufacturing companies in Indonesia with almost the same variable, namely 
CEO Power on company performance and the independent board of commissioners being a moderating variable. (Noval, 20I5).

Based on the description that has described above, so the main issues that will be empirically proven are:

I) How is the study of Islamic Economics about Ownership in the management of an Islamic company?

2) Does Ownership Stock affect the sharia firm's performance?

3) Does the independent commissioner moderate the relationship between Ownership Stock and Sharia Firm Performance?

Based on the main problem above, the researcher develops the initial hypothesis of the study:

I) Ownership in Islamic companies in the study of Islamic economics can provide welfare to many parties.

2) Ownership Stock significantly influences the sharia firm's performance.

3) Independent commissioners moderate the relationship between Ownership Stock and Sharia Firm Performance.

\section{B. THEORITICAL}

\section{Agency Theory}

The agency relationship is an agreement that is understood and agreed upon by the manager (agent) with shareholders/company owners (principal) (Jensen \& Meckling, 1976). The agreement/contract must explain in detail both those related to the duties and functions of the manager as the agent, or the outline of the company's objectives relating to the management of investment funds and the distribution of returns between the manager and the owner of the company. The manager is obliged to take responsibility for everything related to the management of the company that has been mandated by shareholders (Arifin, 2005).

In the relationship between agent and principal, there is a chance of a conflict of interest. Managers who have full control over the company's operations can implement policies that are not in line with the objectives of the owner of the company so that it can encourage the emergence of agency costs. The rate of return received by the manager as a party working for shareholders will be a cost that must be incurred by the company.

Refers to agency theory, the experts have the same opinion that when the company is more oriented to the interests of shareholders, the company will be 
managed by minimizing costs to maximize the company's profit rate, so that with large profits can provide nominal returns on shares that are also high for shareholders.

Under these conditions, an independent commissioner exists as a structure that bridges the interests of agents and principals, an independent commissioner can be a fairer supervisor because he is in a position that is not attached to the company and the independent commissioner has independence from the influence of company managers (Fama \& Jensen, 1983).

\section{Firm Performance}

Firm performance is a reflection of the company's operational and financial circumstances, based on firm performance can also be assessed the level of the financial health of a company in an accounting period. The assessment and analysis of the company's financial situation are carried out using an analysis of its financial performance that has been suggested by several experts.

One of the obligations that must be fulfilled by managers to shareholders is to provide a report on the company's financial performance as proof of the company's management that has managed by the goals set by the founders of the company. Firm performance can be analyzed using many existing analysis tools; among them is the market ratio using the Price per Earning Ratio (PER) method. This ratio becomes the analysis used in company valuations because this ratio is considered as a ratio that can provide assessments that support company performance. On the other hand, practitioners and academics believe that each firm performance analysis tool has its characteristics, and there are strengths and weaknesses so that it cannot fully explain the condition of the company, as well as PER. However, PER remains to be excellent in analyzing the market value of a stock.

The information generated from PER explains the nominal amount that must be invested to get one rupiah from the company's profit. In another explanation, PER can also use as a barometer of the relative prices of stock values (Tandelilin, 2010).

\section{Director Ownership (Ownership Stock)}

Director is the holder of the highest position in a company, and director referred to in this study is the managing director and will be referred to as Ownership Stock. The chief director or also known as the Chief Executive 
Officer (CEO), is the highest position available in a company that is authorized to lead the company and is responsible for the stability of the company. Rezaee, 2012 Explained that top executives are usually chief executive officers (CEO). The managerial function is usually carried out by a management team that also consists of other senior executives.

Ownership is an important source of power (Catherine M. Daily \& Jonathan L. Johnson, I997), because ownership binds the wealth of directors and shareholders, thus complementing strong performance incentives (Fama \& Jensen, 1983). The managing director with substantial ownership is more likely to receive a lower salary (Gomez-Mejia, Tosi, \& Hinkin, 1987) and tends not to resist the threat of expropriation (Ann K. Buchholtz \& Barbara A. Ribbens, I994). However, the Managing Director is vulnerable to selfish bias, so this is considered as poor performance externally (Clapham \& Schwenk, I99I), President directors with strong ownership can maintain their position beyond the point of effectiveness (Warren Boeker, I992). Managing directors who have low numbers of ownership are more likely to be removed from the internal coalition (Ocasio, 1994).

The way that can be taken to eliminate agency costs is by increasing the company's share ownership by managers (Jensen \& Meckling, I976). Policies taken by managers may be the effect of the proportion of share ownership of company control holders. If the manager has shares in the company that he manages, then the manager who also has a role as a shareholder and the position will be aligned with the owner of the company, so that it is expected to have a good direct impact on the policies adopted by the stakeholders in the company.

\section{Ownership in Islamic Economics}

The study of Ownership in Islamic Economics is widely regulated in the Jurisprudence in the fieldsof Al-Mal (property) and Al-Milk (belonging). Ownership theory is regulated in Islam to avoid violating someone's right (property) by another party, because humans tend to have a materialistic nature. Islam recognizes both private and public property rights. Islam also respects property rights as well as provides its rules, such as if a person's property rights have reached a certain amount must be distributed to others. Islam's respect for property rights is clearly reflected in the concept of haq al-adami, besides that the protection of the safety of private property is also given by Islam with the 
determination of criminal sanctions against people who seize it, either through theft or robbery.

Ownership of property is fundamental for every individual in carrying out their activities. Ownership boundaries relating to the number, utilization and freedom of use are strongly influenced by fundamental teachings, both through religious teachings and ideological understanding. In general the boundaries discussed are public and private ownership, the use of business objects and the maximum limit ofownership.

Ownership (al-milk) in languagecan be interpreted to have something and be able to act freely against it. In general, ownership is understood as a dimension of people's mastery of something (goods or objects) and the goods are in their hands both in real and legal terms, so that he has the right to use the maccording to his wishes and no other person, be it an individual or institution, that can prevent obstacles in utilizing the goods. However, from an Islamic point of view it does not mean ownership is absolute. The specificity of the Islamic concept of ownership lies in the fact that in Islam, the legitimacy of ownership depends on morals.

Islam allows individuals to acquire property, whether moving or not, through legitimate means. People can acquire as muchwealth as they can through their knowledge, skills, experiences, and efforts. He can gain as much as he can with his knowledge, skills, experience, and efforts.

The existence of ownership rights, a person can act fully in managing the object she has. Assets held in the form of a business will be utilized optimally to obtain additional assets. In Islam, asset management is expected to provide positive and lawful results for the owner of the property and can provide a good economic impact for the surrounding area.

\section{METHODOLOGY}

\section{Types of research}

This research is field research, using research data from literature and research data in the form of an annual financial report of a Sharia company as a research sample. This research examines previous theories to solve problems that can occur in a company. For this reason, this research category is non-contrived research, because this study does not make artificial arrangements for research, but the data used areas are without any specific settings, so the research takes place normally in a natural environment as it is. 


\section{Population and Sample}

The study population uses sharia companies listed on the Indonesia Sharia Stock Index (ISSI) on the Indonesia Stock Exchange (IDX) in 20I8. The sample is determined based on the purposive sampling method with the following conditions:

I. Sharia companies examined are listed in the Indonesian Sharia Stock Index (ISSI); and

2. Available data needed for research based on 2018.

\section{Data Types and Sources}

This study uses qualitative data from Islamic economic literature and quantitative data in the form of figures obtained from annual financial statements of sharia company publications in the Indonesian Sharia Stock Index (ISSI).

\section{Research variable}

\section{Firm Performance}

Firm performance becomes the dependent variable; firm performance is a reflection of a company's achievements (Maryam, 2018). This research uses market ratios as a measurement tool with Price per Earning Ratio (PER) indicators in assessing firm performance. PER is the ratio of share price per share compared to earnings per share (Suad Husnan, 2008). PER can estimate a company's capacity to make a profit. PER is an indicator used by investors as a basis for calculating shares to sell when the price per earning ratio is high.

\section{Ownership Stock}

The independent variable used is Ownership Stock. Ownership Stock is an important leadership quality and offers many potential benefits for an organization. Share ownership by director reflects the capacity of an individual who has full authority over the wealth they own and manage. So, it can be interpreted Ownership Stock is the capacity of a chief director in exerting their power to the policies they want. Ownership Stock can be measured using variables that pay attention to the proportion of shares owned by the managing director in the company he manages (Combs, Ketchen, Perryman, \& Donahue, 2007).

\section{Independent Commissioner}

An independent commissioner becomes a moderating variable; an independent commissioner is a member of the board of commissioners who is obliged to be a supervisor of the company, an independent commissioner is not an 
employee and is not directly related to the company, and is not part of the company owner. The measurement of the independent commissioner variable in this study is based on the proportion of independent commissioners from the total members of the board of commissioners.

\section{Research Model}

Hypothesis testing uses multiple regression analysis. The development of this research model is used to experiment hypothesis 2 "Ownership Stock has a positive influence on firm performance" and hypothesis 3 "Independent commissioners have a moderating influence on the relationship between Ownership Stock on firm performance". The research model is as follows:

Information:

$$
\mathrm{KiPer}_{\mathrm{i}}=\boldsymbol{\beta}_{0}+\boldsymbol{\beta}_{1} \text { OwnStock }_{\mathrm{w}}+\boldsymbol{\beta}_{2} \text { OwnStock }^{*} \text { KomInd }_{\mathrm{i}}+\boldsymbol{\varepsilon}_{\mathrm{i}}
$$

KiPeri : Firm Performance i.

OwnStocki : Ownership Stock / Share ownership by directorin the company i.

KomIndi $\quad$ : Proportion of independent Commissioners in the company i.

OwnStock

${ }^{*}$ KomIndi

: Interaction between Ownership Stock and independent commissioners i.

\section{Analysis Techniques}

a. Descriptive statistics

The general explanation of the data examined based on the highest value (maximum), lowest (minimum), average (mean), and standard deviation (Ghozali, 2016).

b. Classical Assumption Testing

I) Multicollinearity Testing

Multicollinearity testing aims to be able to see whether the independent variable has a perfect relationship or near-perfect in the research model used. Simple multicollinearity diagnosis based on the value of Variance Inflation Factor (VIF) and Tolerance. If the VIF value $<\mathrm{IO}$ or tolerance value is more than O.I, it means that the model is not affected by multicollinearity (Ghozali, 2016). 


\section{2) Heteroscedasticity Testing}

Heteroscedasticity testing to assess variance inequalities in the research model from residuals of one monitoring to another. The Glejser Test is one of the ways to detect the presence of heteroskedasticity by regressing the absolute residual value of the independent variable (Ghozali, 2016). If it turns out that the independent variable is less than 0.05 or statistically significant effect on the dependent variable, it is an indication of heteroscedasticity, even if the independent variable exceeds 0.05 in influencing the dependent variable, meaning there is no heteroscedasticity.

c. Hypothesis test

\section{I) Coefficient of Determination}

The coefficient of determination $\left(\mathrm{R}^{2}\right)$ is a tool used to measure the capacity of the model in explaining the variations that exist in the dependent variable. The range in nominal terms indicated by the coefficient of determination ranges from zero to one. A small value $\left(R^{2}\right)$ indicates the limited competence of independent variables in explaining the variety of dependent variables. While the value $\left(\mathrm{R}^{2}\right)$ is close to number one, it means that the independent variable can explain the information needed to project variations of the dependent variable.

2) Significant Testing of Individual Parameters (t-Test)

Significant Testing of Individual Parameters ( $t$-test) is to see the effect of each independent variable in describing the dependent variable. If the significance value of the regression results indicates a value of less than $5 \%$ or 0.05 , then the independent variable individually influences the dependent variable.

\section{RESULTS AND DISCUSSION}

\section{Result}

\section{Research data}

This research uses data from sharia companies, and the referred sharia companies were those listed on the Indonesia Sharia Stock Index (ISSI) in 2018. The population of this research is 394 sharia companies. Of the 394 sharia companies, as many as 98 sharia companies were incomplete or were outlier data or data not following the benchmarks set by researchers. So that 296 Islamic companies selected as research samples. 


\section{a. Research result}

1) Descriptive Analysis Results

Descriptive analysis is an analysis that describes the characteristics of the research sample in general. Further discussed in table 4.I illustrates the sample description both as a whole and separately according to the sample group.

\section{Table I}

Descriptive Analysis Results

Descriptive Statistics

\begin{tabular}{|r|r|r|r|r|r|}
\hline & $\mathrm{N}$ & $\begin{array}{c}\text { Minimu } \\
\mathrm{m}\end{array}$ & Maximum & Mean & $\begin{array}{c}\text { Std. } \\
\text { Deviation }\end{array}$ \\
\hline KiPer & 296 & 2376.29 & 3374.540 & $23.42 \mathrm{I} 6$ & 259.75535 \\
& & 00 & 35 & $7 \mathrm{I}$ \\
OwnStoc & 296 & .0000 & .6647 & $.0100 \mathrm{I} 2$ & .0589202 \\
$k$ & 296 & .0000 & $\mathrm{I} .0000$ & .399575 & $.12 \mathrm{I} 5344$ \\
KomInd & 2934 \\
Valid N & 296 & & & & \\
(listwise) & & & & \\
\hline
\end{tabular}

Source: Data processed in 2019

Table I illustrates the mean, minimum, maximum, and standard deviation (level of spread deviations) from this research data. The variables explained are firm performance using Price per Earning Ratio (KiPer) indicators, Ownership Stock measured by share ownership by director (OwnStock), and independent commissioners using a percentage measure of independent commissioners in the composition of the board of commissioners (KomInd).

The table also explains about each variable; the first variable is Price per Earning Ratio using the term KiPer has an average value of 23.4216; the lowest ratio is $-2376,2900$; the highest ratio is 3374.5400; the standard deviation is 259.7554. The mean value shows a figure of $23.42 \mathrm{I} 6$ means that on average, it has a price of 23 times that of net profit.

The second variable, Ownership Stock, using the term designation, OwnStock, shows the result that the average OwnStock in the company is 0.0100; The lowest OwnStock is 0.0000; The highest OwnStock is 0.6647; standard deviation value of 0.0589 . The mean value indicates a value of 0.0100 , 
meaning that the Managing Director, who owns shares of sharia companies in Indonesia, tends to be still very low.

In the independent Commissioner variable abbreviated as KomInd, there is a mean value of KomInd 0.3995; the maximum value of KomInd I,0000; KomInd minimum value is 0.0000 ; standard deviation value of 0.I2I5. The mean value of $39.95 \%$ indicates that the average of Islamic companies is sufficient at a minimum threshold of $30 \%$ of the proportion of independent commissioners from all board of commissioners.

2) Classic Assumption Test Results

a) Multicollinearity Testing Results

Explanation from Ghozali, 2016, multicollinearity testing was carried out to check the research model, which proves the correlation between independent variables. The research model considered good if no correlation found between the independent variables. The results of testing the research model are explained in table 2 as follows:

Table 2

Multicollinearity Testing Results

Coefficients $^{a}$

\begin{tabular}{|rr|r|c|}
\hline & & \multicolumn{2}{|c|}{ Collinearity Statistics } \\
\cline { 3 - 4 } & Model & Tolerance & VIF \\
\hline I & OwnStock & .998 & I.002 \\
& KomInd & .998 & I.002 \\
\hline
\end{tabular}

a. Dependent Variable: Kiper

Source: Data processed in 2019

The independent variable test results above explain the tolerance value of Ownership Stock (OwnStock) 0.998, which is higher than the standard value of 0.10 while the VIF is I.002 lower than the standard value of IO. A variable proportion of independent commissioners (KomInd) has a tolerance value of 0.998, which means higher than 0.I0, while the VIF is I.002 lower than IO.

b) Heteroscedasticity Testing Results

Proof of whether or not the similarity of variance occurs from one variable to another variable in the research model requires heteroscedasticity testing. Heteroscedasticity occurs when the value of the residual variance of research to other studies is different, whereas if the value is constant, then this means there is homoscedasticity. When heteroscedasticity occurs, then the regression model is considered not good., so the characteristics of a good regression 
model are those that do not contain heteroscedasticity (Ghozali, 2016). This test uses the Glejser test as a technique used to check for the presence of heteroscedasticity (Ghozali, 2016). The results of glacier tests that have been carried out will be explained in the table below:

Table 3

\section{Heteroscedasticity Testing Results}

\section{Coefficients $^{2}$}

\begin{tabular}{|c|c|c|c|c|c|}
\hline \multirow[b]{2}{*}{ Model } & \multicolumn{2}{|c|}{$\begin{array}{l}\text { Unstandardized } \\
\text { Coefficients }\end{array}$} & \multirow{2}{*}{$\begin{array}{l}\text { Standardize } \\
\text { d } \\
\text { Coefficients } \\
\text { Beta }\end{array}$} & \multirow[b]{2}{*}{$\mathrm{T}$} & \multirow[b]{2}{*}{ Sig. } \\
\hline & B & Std. Error & & & \\
\hline $\begin{array}{ll}\text { I } & \text { (Consta } \\
& n t)\end{array}$ & -14.200 & 50.599 & & $-.28 \mathrm{I}$ & .779 \\
\hline $\begin{array}{l}\text { OwnSto } \\
\text { ck }\end{array}$ & 233.590 & 249.085 & .055 & .938 & .349 \\
\hline KomInd & I8I.I20 & I20.757 & .087 & 1.500 & .135 \\
\hline
\end{tabular}

a. Dependent Variable: AbsUt

Source: Data processed in 2019

The table explains the variable Ownership Stock (OwnStock) has a significance value of 0.349 and the proportion of independent directors (KomInd) of 0.135, which means there are no independent variables that affect the value of Absolut $\mathrm{Ut}(\mathrm{Abs} U \mathrm{t})$ as the dependent variable. Evidenced by the significance values of the two variables above the value of 0.05 . So that the conclusion states the research model is free from heteroscedasticity.

3) Hypothesis Testing Results

a) Determination Coefficient Test Results

The coefficient of determination $\left(R^{2}\right)$ is a step in checking the capacity of a predetermined research model to explain the variations that exist in the use of independent variables. The results of the coefficient of determination will be in the range of zero $(0)$ to one $(\mathrm{I})$. The greater the capacity of the independent variable in explaining the dependent variable, the greater the value shown from $R^{2}$. The reverse also applies, namely, the smaller the capacity of the independent variable in explaining the dependent variable, the value of $\mathrm{R}^{2}$ will also be small. The results of testing the coefficient of determination are in the table below: 
Tabel 4

Determination Coefficient Test Results $\left(\mathrm{R}^{2}\right)$ Model Summary

\begin{tabular}{|r|c|r|r|r|}
\hline $\begin{array}{r}\text { Mode } \\
\text { 1 }\end{array}$ & R & R Square & $\begin{array}{c}\text { Adjusted R } \\
\text { Square }\end{array}$ & $\begin{array}{r}\text { Std. Error of } \\
\text { the Estimate }\end{array}$ \\
\hline I & $.134^{\mathrm{a}}$ & .018 & $.0 \mathrm{II}$ & $\begin{array}{r}258.299378 \\
\mathrm{I}\end{array}$ \\
\hline
\end{tabular}

a. Predictors: (Constant), ModerateI, OwnStock

Source: Data processed in 2019

Table 4 proves that the test results show an adjusted $\mathrm{R}$ Square value of 0.0I I (I.I\%). Nominal 0.0II obtained shows that I.I\% of firm performance as the dependent variable is explained by share ownership by the president director in Sharia companies as well as the moderating role of the proportion of independent directors.

b) Significant Test Results of Individual Parameters (t-Test)

Significant testing of individual parameters ( $t$-test) is carried out to get the results about the effect of each independent variable on the dependent variable by looking at the other independent variables that are constant. T-test results are in the following table:

\section{Tabel 5}

Significant Test Results of Individual Parameters ( $t$-Test)

\section{Coefficients $^{2}$}

\begin{tabular}{|c|c|c|c|c|c|}
\hline \multirow[b]{2}{*}{ Model } & \multicolumn{2}{|c|}{$\begin{array}{l}\text { Unstandardized } \\
\text { Coefficients }\end{array}$} & \multirow{2}{*}{$\begin{array}{l}\text { Standardize } \\
\text { d } \\
\text { Coefficients } \\
\text { Beta }\end{array}$} & \multirow[b]{2}{*}{$\mathrm{t}$} & \multirow[b]{2}{*}{ Sig. } \\
\hline & B & Std. Error & & & \\
\hline I (Constant & 27.338 & I5.256 & & 1.792 & .074 \\
\hline $\begin{array}{l}\text { OwnStoc } \\
\mathrm{k}\end{array}$ & 36I4.I37 & 1764.497 & .820 & 2.048 & $.04 \mathrm{I}$ \\
\hline $\begin{array}{l}\text { Moderate } \\
\text { I }\end{array}$ & -I097I.I 57 & $5030.01 \mathrm{I}$ & -.873 & $-2.18 I$ & .030 \\
\hline
\end{tabular}

a. Dependent Variable: KiPer

Source: Data processed in 2019 
- Hypothesis I

The positive results above (2,048) indicate that ownership in Islamic companies can have a positive effect on the company in general and for stakeholders in particular. This positive result can also be interpreted that the company's management of ownership is well managed. This proves that ownership managed with can give a good impact to the surrounding, in accordance with the picture in Islamic economic theory.

- Hypothesis 2

A significant test results on individual parameters to prove hypothesis 2 is set out in table 4.5. T value on the variable Ownership Stock (OwnStock) 2.048 with a significance value of $0.04 \mathrm{I}$. Significance with a value of $0.04 \mathrm{I}$ lower than the 0.05 standard means that Ownership Stock affects the variable Firm Performance (KiPer). The results shown prove that hypothesis 2, which says ownership stock affects firm performance, is positively significantly proven empirically.

- Hypothesis 3

Table 4.5 also shows the $t$ value for the moderating variable percentage of independent directors of -2, I8I with a significance of 0.030 . The significance of 0.030 is lower than the standard value of 0.05 , proving that there is a moderating influence of the independent commissioners on the relationship between Ownership Stock and Firm Performance. Thus, hypothesis 3, which reads as Independent Commissioner, moderate the relationship between Ownership Stock and Firm Performance proved empirically.

\section{b. Discussion}

1) Ownershipon Islamic Economic Perspective

Ownership is a complicated matter that can cause complications. In Islamic economics, every individual has the right to own an item or business, but must pay attention to the norms in gaining ownership. In the study of Islamic economics too, the assets / businesses needed must be in an object that is not approved by the Shari'a, and can also be useful for the owner of the object and the parties around it.

With a well-managed ownership, it will have a positive impact on individuals and society, as contained in the theory of ownership in Islam that each individual ownership also has an obligation to be able to prosper both personally and the community (employees and shareholders). 
The results of the above study show the same thing with the theory presented in Islamic Economics. The company manager, in this case is the director, who has ownership rights in the Sharia company that he manages can have a positive influence on the company's performance. This positive effect on company performance can clearly benefit the company's growth. Replace this for investors, shareholders and investors.

2) Ownership Stock on Firm Performance

Hypothesis 2 statement that says ownership stock significantly influences firm performance empirically proven. These results are seen based on the probability value of the significance of Share Ownership with the president director shareholding indicator 0.04I lower than 0.05. Descriptive analysis results explain the minimum value of ownership stock of 0.0000 , the maximum value of 0.6647 and the average value of 0.010012 while the results of descriptive analysis of firm performance with Price per Earning Ratio indicator obtain a minimum value of -2376.29 , a maximum value of 3374.54 and the average value is $23.42 \mathrm{I} 635$.

Ownership Stock in Islamic companies in this study is very low, which is only I5 companies or $5.07 \%$ of the sample, which has an above-average Ownership Stock of 0.0IO0I2. While 28I Sharia companies or $94.93 \%$ others have Ownership Stock below the average level of 0.0I00I2. Firm performance as indicated by Price per Earning Ratio also has a level of firm performance below the average level of Firm Performance that is 23.42 I635, with Islamic companies whose performance levels are above the average of 78 companies from 296 sample companies, or as many as $26.35 \%$ of companies have a level of Price per Earning Ratio above the average, while $73.65 \%$ or 2 I8 companies have below-average performance levels.

The results of testing the hypotheses that prove Ownership Stock has value relevance related to firm performance are in line with Combs et al., 2007 and Sekaredi, 20II. Jensen \& Meckling, 1976, also first gave an opinion similar to this research, which stated the desire of managers to work optimally in manage the company as well as possible to maximize the performance of the company will be higher in line with the amount of share ownership by the manager.

3) The Role of Independent Commissioner Moderating Variables in the Relationship Between Ownership Stock and Firm Performance 
The probability value of the significance of the independent commissioner's moderating function on the relationship of Ownership Stock and firm performance is less than 0.05, which indicates that hypothesis 3 , which states that an independent commissioner has a moderating influence on the relationship between Ownership Stock on Firm Performance is empirically proven. The results of the descriptive analysis obtained the minimum value of an independent commissioner of 0.0000 , the maximum value of 1.0000 and an average calculation of 0.399575 then the results of the descriptive analysis of company performance revealed a maximum value of 3374.54 , a minimum value of -2376.29 , and a value of the average is 23.421635 .

Independent Commissioners in the companies that became the study sample have shown a relatively good proportion, which is $43.58 \%$, or as many as I29 Islamic companies have a proportion of independent commissioners above the average of 0.3773 of the sample. While the remaining $56.42 \%$ or 167 companies have a proportion of independent commissioners below $23.42 \%$ as an average value, however, when viewed from existing regulations, namely the board of commissioners must have at least $30 \%$ independent commissioners from the overall board of commissioners, the results show a very good value of $93.92 \%$ having a percentage of independent commissioners exceeding 30\% and only $6.08 \%$ has still not reached the proportion of 30\%.

Value of Ownership Stock in this research is very low, with only I5 companies or $5.07 \%$ of the sample having Ownership Stock above the average of 0.0I00I2. While $94.93 \%$ of other companies have share ownership values below the average level of 0.0IO0I2. The company's performance which is indicated by Price per Earning Ratio also has a level of corporate performance is still below the average level of Firm Performance that is 23.42I635, with details of companies whose level of performance is above the average of 78 companies from 296 sample companies, or as much as $26.35 \%$ of companies still have above-average price per earning ratio, while $73.65 \%$ or 218 companies have below-average performance levels.

Research that proves the results that the board of commissioners moderates the relationship of Ownership Stock and firm performance is contrary to the results of research by previous researchers with manufacturing companies listed on the Indonesia Stock Exchange (IDX) as research objects 
(Noval, 2015) which states that an independent board of commissioners does not moderate the relationship of CEOs who own shares and the company's performance. Bukhori \& Rahardja, 2012, also shows different results, firstly using variable company size, total directors, and no significant influence from the board of commissioners on the performance of a company.

Research from Paul, Friday, \& Ohiokha Godwin, 20II, which uses the variable non-executive external commissioners states that the composition of the external board and performance do not have a mutually influential relationship and do not have a positive economic impact even though it may have several other benefits to the company.

Independent commissioners do not provide any added value because they do not have supervisory positions, lack of adequate qualifications, and competencies from independent commissioners (Rashid, Zoysa, Lodh, \& Rudkin, 2010). Combs et al., 2007 said an external board of commissioners was needed to oversee the authority of director, but monitoring by other executives provided sufficient constraints on directors with low powers, although regulatory trends increasingly supported the board of commissioners who were dominated by external parties, findings this research shows that this does not always benefit share holders.

Similar research results have been conducted, namely from Haryono, Fitriany, \& Eliza Fatima, 2017, which proves that capital structure and institutional ownership affect the company's performance variable with the indicator used that is ROE. Jackling \& Johl, 2009 and Eka Hardikasari, 20I I states that there is a positive effect resulting from the relationship between the size of the board composition on company performance, following the opinion that the external environment can increase access to various resources which in turn can also improve performance.

\section{E. CONCLUSION}

The purpose of this research is to examine Islamic Economic Perspective about Ownership, the effect of the relationship of Ownership Stock on company performance variables and to examine the effect of moderation of independent commissioners on the relationship of Ownership Stock and company performance. Based on the results of the study concluded:

I. The results of the first hypothesis test show that company ownership in the data studied is in line with ownership in an Islamic economic perspective. The 
results illustrate that ownership can provide prosperity to the company, owners, managers and can also attract the interest of potential investors.

2. The results of testing the second hypothesis between Ownership Stock and Sharia Firm Performance show a significant effect. The results of this test prove that Ownership Stock affects Sharia Firm Performance. In other words, the shareholding of a president director in a Sharia company can influence the level of performance of a company.

3. The results of the third hypothesis test prove that the Independent Commissioner moderates the relationship of Ownership Stock and Sharia firm performance. It can also mean that the number of independent commissioners in a Sharia company can influence the ability of the President Director to improve company performance.

\section{REFERENCES}

Ann K. Buchholtz, \& Barbara A. Ribbens. (1994). Role of Chief Executive Officers in Takeover Resistance: Effects of CEO Incentives and Individual Characteristics. The Academy of Management Journal, 37(3), 554-579.

Arifin. (2005). Peran Akuntan dalam Menegakkan Prinsip Good Corporate Governance pada Perusahaan di Indonesia (Tinjauan Perspektif Teori Keagenan). Semarang: Diponegoro University Press.

Bashir, Ahmad Azhar. (1993). Refleksi atas Persoalan Keislaman. Bandung: Mizan

Baysinger, B. D., \& Butler, H. N. (I985). Corporate Governance and the Board of Directors: Performance Effects in Board Composition. Journal of Law, Economics and Organization, $I(\mathrm{I})$, IOI.

Bukhori, I., \& Rahardja. (2012). Pengaruh Good Corporate Governance Dan Ukuran Perusahaan Terhadap Kinerja Perusahaan (Studi Empiris pada Perusahaan yang Terdaftar di BEI 2010). Diponegoro Journal of Accounting, $I(\mathrm{I})$.

Catherine M. Daily, \& Dan R. Dalton. (1992). The Relationship between Governance Structure and Corporate Performance in Entrepreneurial Firms. Journal of Business Venturing, 75), 375-386.

Catherine M. Daily, \& Jonathan L. Johnson. (I997). Sources of CEO Power and Firm Financial Performance: A Longitudinal Assessment. Journal of Management, 23(2), 97. 
Chaganti, R. S., Mahajan, V., \& Sharma, S. (I985). Corporate Board Size, Composition and Corporate Failures in Retailing Industry. Journal of Management Studies, 22(4), 400-4I7. https://doi.org/I0.I I I I/j.I4676486.1985.tb00005.x

Cho, D.-S., \& Kim, J. (2007). Outside Directors, Ownership Structure and Firm Profitability in Korea. Corporate Governance: An International Review, I5(2), 239-250. https://doi.org/I0.I I I I/j.I467-8683.2007.00557.x

Clapham, S. E., \& Schwenk, C. R. (I99I). Self-serving attributions, managerial cognition, and company performance. Strategic Management Journal, I2(3), 2I9-229. https://doi.org/I0.I002/smj.4250I20305

Combs, J. G., Ketchen, D. J., Perryman, A. A., \& Donahue, M. S. (2007). The Moderating Effect of CEO Power on the Board Composition?Firm Performance Relationship. Journal of Management Studies, $O(0)$, 070605080020003-??? https://doi.org/IO.IIII/j.I4676486.2007.00708.x

Deni Darmawati, Khomsiyah Khomsiyah, \& Rika Gelar Rahayu. (2005). Hubungan Corporate Governance dan Kinerja Perusahaan. The Indonesian Journal of Accounting Research, 8(2). https://doi.org/I0.333I2/ijar.I3I

Dunn, P. (2004). The Impact of Insider Power on Fraudulent Financial Reporting. Journal of Management, 30(3), 397-4I2. https://doi.org/I0.10I6/j.jm.2003.02.004

Eka Hardikasari. (20II). Pengaruh Penerapan Corporate Governance Terhadap Kinerja Keuangan Pada Industri Perbankan Yang Terdaftar Di Bursa Efek Indonesia (Bei) Tahun 2006-2008. Universitas Diponegoro, Semarang.

Fama, E. F., \& Jensen, M. C. (I983). Separation of Ownership and Control. The Journal of Law and Economics, 26(2), $30 \mathrm{I}$.

Frankforter, S. A., Berman, S. L., \& Jones, T. M. (2000). Boards of Directors and Shark Repellents:Assessing the Value of an Agency Theory Perspective. Journal of Management Studies, 37(3), 32I-348. https://doi.org/IO.I I I I I I467-6486.00I83

Ghozali, I. (2016). Aplikasi Analisis Multivariate Dengan Program IBM SPSS 23. Semarang: Badan Penerbit Universitas Diponegoro.

Gomez-Mejia, L. R., Tosi, H., \& Hinkin, T. (I987). Managerial Control, Performance, And Executive Compensation. Academy of Management Journal, 3O(I), 5I-70. https://doi.org/I0.2307/255895 
Gunawan, Agus. (2017). Kepemilikan Dalam Islam. TAZKIYA Jurnal Keislaman, Kemasyarakatan \& Kebudayaan. Vol.18 No.2

Hanafi, Syafiq M. (2007). Sistem Ekonomi Islam \& Kapitalisme : Relevansi Ajaran Agama Islam dalam Aktivitas Ekonomi. Yogyakarta: Cakrawala

Haryono, S. A., Fitriany, \& Eliza Fatima. (2017). Pengaruh Struktur Modal Dan Struktur Kepemilikan Terhadap Kinerja Perusahaan. Jurnal Akuntansi dan Keuangan Indonesia, I4(2), 22.

Hermalin, B. E., \& Weisbach, M. S. (I99I). The Effects of Board Composition and Direct Incentives on Firm Performance. Financial Management, 20(4), IOI. https:// doi.org/I0.2307/36657I6

Jackling, B., \& Johl, S. (2009). Board Structure and Firm Performance: Evidence from India's Top Companies. Corporate Governance: An International Review, IT(4), 492-509. https://doi.org/I0.IIII/j.I4678683.2009.00760.x

Jensen, C., \& Meckling, H. (1976). Theory of The Firm: Managerial Behavior, Agency Costs and Ownership Structure. Journal of Financial Economics, $3(4), 305$.

Khan, A., \& Awan, S. H. (2012). Effect of Board Composition On Firm's Performance: A Case Of Pakistani Listed Companies. Interdisciplinary Journal Of Contemporaty Research In Business, 3(10), 853.

Larcker, D. F., \& Tayan, B. (20I2). Is a Powerful CEO Good or Bad for Shareholders? SSRN Electronic

Journal. https://doi.org/I0.2I39/ssrn.2I75I9I

Lusiana, F. W., \& Chabachib, D. H. M. (2010). Analisis Pengaruh Rasio Likuiditas, Rasio Solvabilitas, Rasio Aktivitas, Dan Rasio Profitabilitas Terhadap Price Earning Ratio Pada Perusahaan Manufaktur Yang Terdaftar Di Bursa Efek Indonesia. 29.

Mannan, M. Abdul. (1997). Teori dan Praktek Ekonomi Islam. Yogyakarta: Dana Bhakti Prima Yasa

Mark S. Beasley. (1996). An Empirical Analysis of the Relation between the Board of Director Composition and Financial Statement Fraud. The Accounting Review, 7I(4), 443-465.

Maryam, D. (20I8). Pengaruh Struktur Modal dan Ukuran Perusahaan Terhadap Agency Cost dan Kinerja Perusahaan (Studi Pada Perusahaan Manufaktur Sektor Industri Barang Konsumsi Yang Terdaftar Di Bursa Efek 
Indonesia). Jurnal Akuntansi dan Pajak, I8(2), 196. https://doi.org/I0.29040/jap.vI8i2.I55

Mpataa, K. A., \& Sartono, A. (1997). Factor Determining Price per Earning Ratio. Kelola, $V I(5)$.

Musa, M. Yusuf Musa (1954). Al-Fiqh Al-Islami. Kairo: Dar Al-Kutub AlHadithah

Nasution, M., \& Setiawan, D. (2007). Pengaruh Corporate Governance Terhadap Manajemen Laba Di Industri Perbankan Indonesia. 26.

Noval, M. (2015). Pengaruh CEO Power Terhadap Kinerja Perusahaan Dengan Peran Komisaris Independen Sebagai Variabel Moderasi (Studi Pada Perusahaan Yang Terdaftar Di Bursa Efek Indonesia). Jurnal Ilmu Manajemen dan Akuntansi Terapan (JIMAT), 6(2), 88.

Ocasio, W. (1994). Political Dynamics and the Circulation of Power: CEO Succession in U.S. Industrial Corporations, 1960-1990. Administrative Science Quarterly, 39(2), 285. https://doi.org/I0.2307/2393237

Parulian, S. R. (2004). Analisis hubungan antra komite audit dan komisaris independent dengan praktek manajemen laba: Studi empiris perusahaan di BEJ. I.

Paul, A., Friday, O., \& Ohiokha Godwin. (20II). Board Composition and Corporate Performance: An Analysis of Evidence from Nigeria. Research Journal of Finance and Accounting, 2(4), II.

Rashid, A., Zoysa, A. D., Lodh, S., \& Rudkin, K. (2010). Board Composition and Fitm Performance: Evidence from Bangladesh. 22.

Rechner, P. L., \& Dalton, R. D. (I986). Board composition and shareholders wealth: An empirical assessment. International Journal of Management, $3(2), 86$.

Rezaee, Z. (2012). Corporate Governance Post-Sarbanes- Oxley: Regulations, Requirements, and Integrated Processes. New Jersey: John Wiley \& Sons, Inc.

Sari, F. W. (2012). Pengaruh Tata Kelola Perusahaan Terhadap Luas Pengungkapan Sukarela (Studi Empiris Pada Perusahaan Manufaktur Yang Terdaftar Di BEI Tahun 2008 - 20II). Universitas Atma Jaya, Yogyakarta. 
Schellenger, M. H., Wood, D. D., \& Tashakori, A. (1989). Board of Director Composition, Shareholder Wealth, and Dividend Policy. Journal of Management, I5(3), 457-467. https://doi.org/IO.II77/0I4920638901500308

Sekaredi, S. (20II). Analisi Pengaruh Corporate Governance Terhadap Kinerja Keuangan Perusahaan. 30.

Suad Husnan. (2008). Dasar-dasar Manajemen Keuangan (Keputusan Jangka Panjang) (4th ed.). Yogyakarta: BPFE.

Tandelilin, E. (20I0). Portofolio dan Investasi, Teori dan Aplikasi. Yogyakarta: Kanisius.

Tutut Dwi Andayani. (2010). Pengaruh Karakteristik Dewan Komisaris Independen Terhadap Manajemen Laba (Studi Pada Perusahaan Manufaktur yang Terdaftar di Bursa Efek Indonesia). Universitas Diponegoro, Semarang.

Wahyudi, U., \& Pawestri, H. P. (2006). Implikasi Struktur Kepemilikan Terhadap Nilai Perusahaan: Dengan Keputusan Keuangan Sebagai Vaiabel Intervening. 25.

Warren Boeker. (1992). Power and Managerial Dismissal: Scapegoating at the Top. Administrative Science Quarterly, 37(3), 400-42I. 
Ownership on Islamic Economic Perspective and Director Ownership on Sharia Companies with Moderation Roles of Independent Commissioners

Muhammad Noval ${ }^{1}$, Rani Raharjanti ${ }^{2}$, Musab A. M. Ali ${ }^{3}$ 